\title{
Pulsed galvanostatic control of a solid-contact ion-selective electrode for potentiometric biosensing of microcystin-LR
}

\author{
Nana $\mathrm{Yu}^{\mathrm{a}, \mathrm{b}}$, Jiawang Ding ${ }^{\mathrm{a}, *}$, Wenwei Wang ${ }^{\mathrm{b}}$, Xuedong Wang ${ }^{\mathrm{b}, *}$, Wei Qin ${ }^{\mathrm{a}}$ \\ ${ }^{a}$ Key Laboratory of Coastal Environmental Processes and Ecological Remediation, Yantai Institute of Coastal Zone Research (YIC), Chinese Academy of \\ Sciences (CAS), Shandong Provincial Key Laboratory of Coastal Environmental Processes, YICCAS, Yantai, Shandong 264003, PR China \\ ${ }^{\mathrm{b}}$ Department of Environmental Sciences, Key Laboratory of Watershed Science and Health of Zhejiang Province, Wenzhou Medical University, Wenzhou \\ 325035, PR China
}

\section{A R T I C L E I N F O}

\section{Article history:}

Received 12 November 2015

Received in revised form 18 February 2016

Accepted 25 February 2016

Available online 27 February 2016

\section{Keywords:}

Chronopotentiometry

Solid-contact ion-selective electrodes

Protein phosphatases

Microcystin-LR

\begin{abstract}
A B S T R A C T
We report here on the development of a chronopotentiometric assay for microcystin-LR based on enzymatic inhibition. The inhibition of protein phosphatase by microcystin-LR can be sensed potentiometrically by using 4-nitrophenyl phosphate as an enzyme substrate. A solid-contact ion-selective electrode (ISE) with poly(3,4-ethylenedioxythiophene)-poly(styrenesulfonate) as a transduction layer has been designed for potentiometric biosensing using the pulsed galvanastatic technique. By applying an anodic current, the enzymatic generated $p$-nitrophenol can be extracted into the polymeric membrane with tetradodecylammonium tetrakis(4-chlorophenyl)-borate to produce the chronopotentiometric signal. Meanwhile, a controlled voltage was applied to refresh the membrane for multiple consecutive measurements. The proposed potentiometric assay showed a linear response for microcystin-LR in the range $1-100 \mu \mathrm{g} / \mathrm{L}$ with a detection limit of $0.5 \mu \mathrm{g} / \mathrm{L}(3 \sigma)$. We believe that the proposed method can be employed for sensitive, rapid and reliable determination of analytes involved in enzyme inhibition.
\end{abstract}

(c) 2016 Elsevier B.V. All rights reserved.

\section{Introduction}

Microcystins (MCs) are a class of toxins produced by different species of cyanobacteria. To date, more than 70 structural variants of MCs with different toxicity levels have been discovered, among which microcystin-LR (MC-LR) is the most toxic and widely studied cyanotoxins [1-3]. MCs are usually occurring in fresh water, which can lead to the animal poisoning episodes and human health problems. In recent years, cases of human intoxication have been reported in China and around the world [4,5]. Accordingly, World Health Organization (WHO) has established a provisional guideline value of $1.0 \mu \mathrm{g} / \mathrm{L}$ for MCs in drinking water [6]. To assure water quality and protect human health, a sensitive, rapid and simple analytical method is highly desired to measure low concentrations of MCs in aquatic environment.

Up to now, chromatographic techniques with different detection principles such as, UV absorption and mass spectrometry are prior options to identify the variants and quantify the concentrations of MCs in aquatic environment [7-9]. Capillary electrophoresis has also been applied to the separation and anal-

\footnotetext{
* Corresponding author.

E-mail addresses: jwding@yic.ac.cn (J. Ding), zjuwxd@163.com (X. Wang).
}

ysis of MCs [10]. These methods can provide accurate results but have the drawbacks of intensive labor and time-consuming procedures. Recently, the development and applications of biosensors for rapid and sensitive detection of MCs have received considerable attention [11]. Among them, antibody-based immunoassays are particularly suitable for high-throughput analysis and would be promising for the routine screening of MCs contamination [12-14]. However, the tedious procedures for the preparation of the antibodies may limit their wide applications. Recently, alternative biosensors using aptamers as bioreceptors have been proposed $[15,16]$. Unfortunately, the selected aptamers are available only to a few microcystin congeners.

Previous research has shown that MCs display a potent and specific inhibition of serine/threonine protein phosphatases such as protein phosphatases 1 (PP1) and 2A (PP2A) [17,18]. Bioassays based on the protein phosphatase inhibition have been developed, which provide an attractive way to carry out MCs screening and indicate the toxicity of the sample. Although some improvements in specificity are still required, these biosensors have significant advantages over current analytical methods in respect to analysis time, cost and simplicity. To this end, a number of biosensors based on optical and electrochemical transductions have been designed [2,3,19-21]. Compared to colorimetric methods, electrochemical biosensors could provide lower detection limits for MCs. However, 
for amperometric biosensors, the oxidation of the corresponding electroactive dephosphorylated phenols to quinones on the electrode surface may cause electrode fouling [11]. Therefore, new biosensors are still highly desired to meet the demands for sensitive detection of MCs.

In recent years, potentiometry based on ion-selective electrodes (ISEs) have evolved to provide a promising transducer for biosensing [22-26]. Typically, these electrodes have been extensively investigated for biosensing via zero-current potentiometry. Alternatively, ion-selective membranes can be interrogated under galvanostatic control and used for the chronopotentiometric detection in analogy to zero-current potentiometry $[27,28]$. The discovery of pulsed galvanostatic ion sensors, which work under periodic galvanostatic polarization, can provide a rapid, reproducible and continuous potentiometric sensing format with improved upper detection limit, sensitivity, selectivity and reversibility [29-32]. In addition, chronopotentiometry has been found useful in speciation analysis and gives information on the labile ion concentration in the sample [33]. More recently, Bakker's group developed chronopotentiometric sensors using the transition time as the analytical signal [34]. In this attractive sensing protocol, the performance could be improved with utilization of thin polypropylene membranes [35]. To date, galvanostatically controlled ion-selective sensors for both anions and cations have been reported [28]. Very recently, solid contact ISEs with ion-to-electron transducers that can initiate the sensing process at the membranesample interface has been reported [36]. Moreover, it is possible to adjust the standard potential of solid-contact ISE by applying current pulses [37]. However, to the best of our knowledge, not so many efforts have been made to investigate the pulsed galvanostatic controlled solid-contact ISEs for potentiometric biosensing [38]. In this work, a solid-contact ISE was designed for potentiometric detection of MC-LR using the pulsed galvanastatic technique. The PP1 catalyzes the hydrolysis of the $p$-nitrophenyl phosphate ( $p$-NPP) to generate $p$-nitrophenol ( $p$-NP), which can be measured potentiometrically in a simple, rapid and reproducible way. It will be shown that the pulsed galvanastatic technique allows MC-LR to be detected efficiently via enzyme inhibition.

\section{Experimental}

\subsection{Reagents and materials}

2-Nitrophenyl octyl ether (o-NPOE), tetradodecylammonium tetrakis(4-chlorophenyl)-borate (ETH 500), high molecular weight poly(vinyl chloride) (PVC), poly(3,4-ethylenedioxythiophene)poly(styrenesulfonate) (PEDOT-PSS, $1.3 \%$ in $\mathrm{H}_{2} \mathrm{O}$, high-conductivity grade), $p$-nitrophenyl phosphate disodium salt hexahydrate and tris(hydroxymethyl)-aminomethane (Tris) were purchased from Sigma. Microcystin-LR was purchased from Enzo Life Sciences. Protein phosphatases $1(2500 \mathrm{U} / \mathrm{mL})$ was purchased from New England Biolabs. Aqueous solutions were prepared with freshly deionized water (18.2 $\mathrm{M} \Omega \mathrm{cm}$ specific resistance) obtained with a Pall Cascada laboratory water system.

\subsection{ISE Preparation and EMF measurements}

The ion-selective membranes contained $10 \mathrm{wt} \%$ ETH 500, $45 \mathrm{wt} \% \mathrm{o}-\mathrm{NPOE}$, and $45 \mathrm{wt} \%$ PVC. The membrane electrodes were prepared as described before with some modifications [39]. A $10 \mu \mathrm{L}$ of PEDOT-PSS was dropped on the glass carbon (GC) electrode surface and air dried. Solid-contact ISEs were prepared by drop-casting $80 \mu \mathrm{L}$ of the membrane cocktail on the GC/PEDOT-PSS electrodes. After being dried for $12 \mathrm{~h}$ at room temperature, the membranes were conditioned in a $50 \mathrm{mM}$, pH 8.4 Tris buffer solution overnight.
All the measurements of potentiometric detections were carried out at $20 \pm 2{ }^{\circ} \mathrm{C}$ using a $\mathrm{CHI} 760 \mathrm{D}$ electrochemical workstation (Shanghai Chenhua Apparatus Corporation, China). A conventional three-electrode cell was used for chronopotentiometric measurements [40]. The pulsed galvanostatic sensing procedures were employed as described before [40,41]. Briefly, an external anodic current of $5 \mu \mathrm{A}$ with a duration of $1 \mathrm{~s}$ was first applied for the extraction of the anion into the membrane to produce the chronopotentiometic response. Then, a controlled voltage at the open-circuit potential in the absence of analyte was used to refresh the membrane with a recovery time of $90 \mathrm{~s}$ for multiple consecutive measurements. The Tris buffer solution ( $50 \mathrm{mM}, \mathrm{pH} 8.4)$ was used as the medium for all the measurements. It should be noted that a higher $\mathrm{pH}$ could increase the amount of detectable $p$-NP ( $\mathrm{pKa}=7.14$ ). However, the optimal pH for PP1 is ca 7.5. As a compromise, $\mathrm{pH} 8.4$ was applied for chronopotentiometric detection of MC-LR.

\subsection{Measurements of PP1 activities}

In this work, the ISE potential was first recorded in Tris buffer containing $2.5 \times 10^{-3} \mathrm{M} p$-NPP to obtain a baseline. For the PP1 activity determination, PP1 at different concentrations was incubated with $50 \mu \mathrm{L}$ of the buffer solution containing $50 \mathrm{mM} p$-NPP at $30^{\circ} \mathrm{C}$ for $5 \mathrm{~min}$. The solution was then heated at $70^{\circ} \mathrm{C}$ for $2 \mathrm{~min}$ to stop the enzymatic catalysis of $p$-NPP. The solution was cooled down to room temperature (ca. $5 \mathrm{~min}$ ). The chronopotentiometric responses were recorded in $1.0 \mathrm{~mL}$ Tris buffer solution. The potential difference ( $\Delta \mathrm{E}_{\mathrm{PP} 1}$ ) between the baseline and the potential measured in the presence of PP1 was used for quantification of enzyme activity.

\subsection{MC-LR detection}

MC-LR was mixed with $100 \mathrm{U} / \mathrm{mL}$ PP1 in $10 \mu \mathrm{L}$ enzyme buffer. Then, the mixture was incubated with $40 \mu \mathrm{L}$ enzyme buffer contained $50 \mathrm{mM} p$-NPP at $30^{\circ} \mathrm{C}$ for $5 \mathrm{~min}$. The solution was then heated at $70^{\circ} \mathrm{C}$ for 2 min to stop the enzymatic catalysis of $p$-NPP. The chronopotentiometric responses were recorded in $1.0 \mathrm{~mL}$ Tris buffer solution. The potential difference between the baseline and the potential response in the presence of PP1 with the MC-LR inhibition was measured ( $\left.\Delta \mathrm{E}_{\mathrm{MC}-\mathrm{LR}}\right)$. The inhibition percentage of MC-LR was calculated as follows:

Inhibition $(\%)=100 \% \times \frac{\left(\Delta \mathrm{E}_{\mathrm{PP} 1}-\Delta \mathrm{E}_{\mathrm{MC}-\mathrm{LR}}\right)}{\Delta \mathrm{E}_{\mathrm{PP} 1}}$

where $\Delta E_{M C-L R}$ and $\Delta E_{P P 1}$ are the potential difference with and without MC-LR inhibition, respectively.

\section{Results and discussion}

\subsection{Characteristics of the pulsed galvanostatic controlled ISE}

In our previous research, we designed a biosensing platform based on the pulsed galvanostatic-controlled release of the substrate ions from the inner filling solution of liquid-contact ISE to the sample solution [40]. In this work, a galvanostatically controlled solid-contact ISE with PEDOT-PSS as a transduction layer was designed for potentiometric biosensing of MC-LR. The electrode membrane, which contains a lipophilic salt ETH500 $\left(\mathrm{R}^{+} \mathrm{R}^{-}\right)$, possesses no ion exchanger properties under zero-current conditions (Scheme 1A). As a transduction layer, PEDOT-PSS was received in a high-conductivity grade, which contains both PEDOT $^{+}$and PEDOT $^{\circ}$ [42]. By applying an anodic current, oxidation of neutral PEDOT film is coupled with anion incorporation [43]. Because of the large molecular weight of the PSS, the lipophilic anions $\left(\mathrm{R}^{-}\right)$ 
A
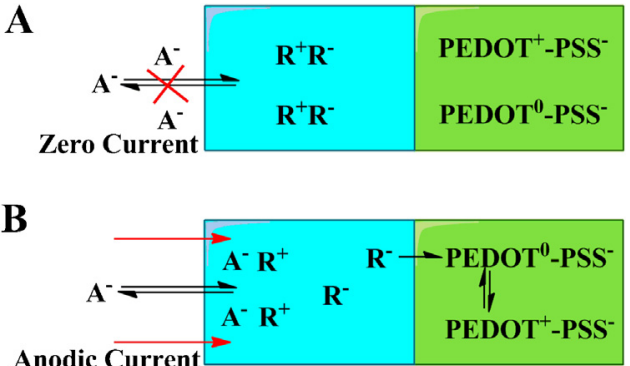

Scheme 1. Schematic illustration of the extraction of anions $\left(A^{-}\right)$into the polymeric membrane under zero-current (A) and current-controlled conditions (B).

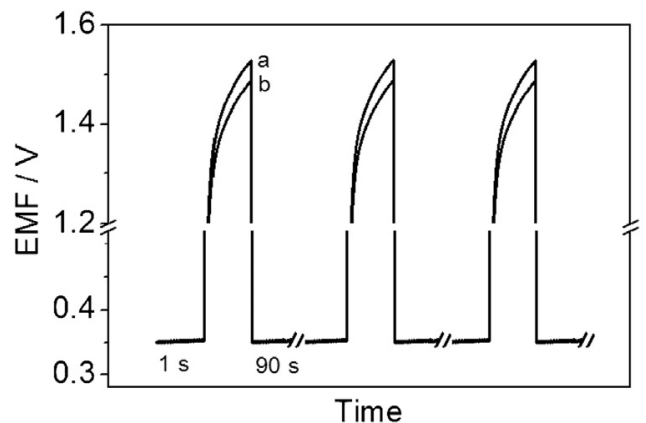

Fig. 1. Potentiometric responses of the pulsed galvanostatic controlled ion-selective electrode with 0 (a), $20 \mathrm{U} / \mathrm{mL}$ PP1 (b) in $1.0 \mathrm{~mL}$ of Tris buffer. PP1 was incubated in $50 \mu \mathrm{L}$ enzyme buffer contained $50 \mathrm{mM} p$-NPP at $30^{\circ} \mathrm{C}$ for $5 \mathrm{~min}$.

will be extracted from the membrane into the conducting polymer phase [44]. Meanwhile, the applied current can force the migration of ion exchanger $\left(\mathrm{R}^{+}\right)$in the opposite direction, which facilitates the extraction of anions $\left(\mathrm{A}^{-}\right)$from the sample solution into the membrane phase to produce a reproducible chronopotentiometric response (Scheme 1B).

In this work, macro-command-controlled procedures for measuring the zero-current potential and current-dependent potential were designed for multiple consecutive measurements. As shown in Fig. 1, under applied anodic current, an abrupt potential change can be seen which results from the IR voltage change [37]. Then the potential is increasing linearly with time as the PEDOT-PSS film is oxidized and accompanied with the extraction of anions into the membrane to produce a reproducible chronopotentiometic response (Fig. 1a). At last, a controlled voltage at the open-circuit potential in the absence of analyte enables the recovery of the membrane for multiple consecutive measurements. In the absence of the $\mathrm{PP} 1$, the anions that can be extracted into are $\mathrm{Cl}^{-}$or $p-\mathrm{NPP}^{2-}$. The presence of the PP1 catalyzes the hydrolysis of $p-\mathrm{NPP}^{2-}$ to generate lipophilic $p-\mathrm{NP}^{-}$, which leads to a current-dependent potential decrease (Fig. 1b). The pulsed galvanostatic controlled ISE exhibits good reproducibility of the potentials with a standard deviation of lower than $1.0 \mathrm{mV}$. More importantly, a defined potential is applied to the membrane for $90 \mathrm{~s}$, which enables the recovery of the membrane for continuous and reversible detection.

\subsection{Determination of protein phosphatase 1}

It is well known that MCs can irreversibly inhibit protein phosphatases type 2A and PP1, which allows protein phosphatase inhibition based assays for the measurements of MCs [3]. Our previous experiments revealed that the $p$-nitrophenol with a higher lipophilicity could show a larger potential response on a polymeric membrane electrode doped with an ion-exchanger [41]. Moreover, a selectivity coefficient of $\operatorname{LogK}_{p-\mathrm{NP}, p-\mathrm{NPP}}^{\text {pot }}=-3.65 \pm 0.2$ has been
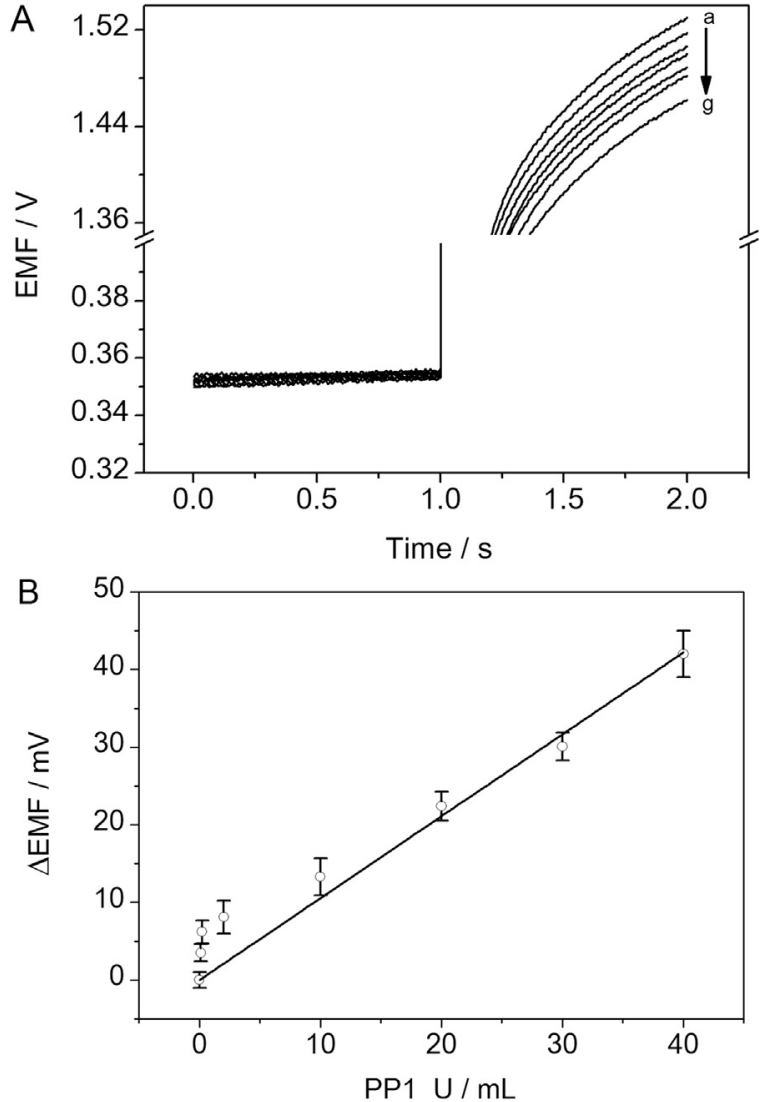

Fig. 2. (A) Potentiometric responses of the electrode with Tris buffer alone (a), and 0 (b), 2 (c), 10 (d), 20 (e), 30 (f), $40 \mathrm{U} / \mathrm{mL}$ (g) of PP1 in $1.0 \mathrm{~mL}$ of Tris buffer. PP1 was incubated in $50 \mu \mathrm{L}$ enzyme buffer contained $50 \mathrm{mM} p$-NPP at $30^{\circ} \mathrm{C}$ for $5 \mathrm{~min}$. (B) The calibration curve for potentiometric detection of PP1. Each error bar represents one standard deviation for three measurements.

determined by the separate solution method. Thus, $p$-NPP was chosen as the substrate for potentiometric detection of MC-LR via PP1 inhibition.

The activities of PP1 were detected by measuring the changes in current-dependent potential, which are induced by the enzymatic generated anions $\left(p-\mathrm{NP}^{-}\right)$. As shown in Fig. $2 \mathrm{~A}$, the currentdependent potentials are shifted to lower values with increase in PP1 activity. Experiments indicate that the potential difference increase linearly with the activity of PP1 over the range of $0.1-40 \mathrm{U} / \mathrm{mL}$ (Fig. $2 B$ ), and the detection limit is $0.05 \mathrm{U} / \mathrm{mL}(3 \sigma)$. It should be noted that larger amount of PP1 can cause larger changes in the potential response, but on the other hand would induce lower sensitivity for the detection of MC-LR. Considering a compromise between wide response range and high sensitivity, $20 \mathrm{U} / \mathrm{mL}$ was employed for the detection of MC-LR.

\subsection{Optimization of the inhibition time}

The effect of inhibition time on the sensor response was investigated. While for the case of irreversible inhibition, a longer incubation time leads to an increase in the degree of inhibition. As shown in Fig. 3, the inhibition rate can increase rapidly with increase of the incubation time up to $10 \mathrm{~min}$ and then tends to increase gradually. In order to achieve a rapid potentiometric sensing with high inhibition efficiency, 5 min was selected as the inhibition time for the enzymatic assay. 


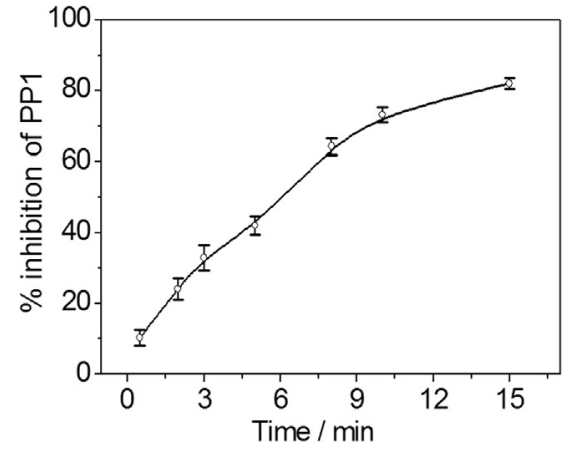

Fig. 3. Effect of inhibition time on the inhibition rate of the $1 \times 10^{-5} \mathrm{~g} / \mathrm{L}$ MC-LR to $20 \mathrm{U} / \mathrm{mL}$ PP1. MC-LR was mixed with $100 \mathrm{U} / \mathrm{mL}$ PP1 in $10 \mu$ L enzyme buffer. Then, the mixture was incubated with $40 \mu \mathrm{L}$ enzyme buffer contained $50 \mathrm{mM} p$-NPP at $30^{\circ} \mathrm{C}$ for $5 \mathrm{~min}$. Each error bar represents one standard deviation for three measurements.

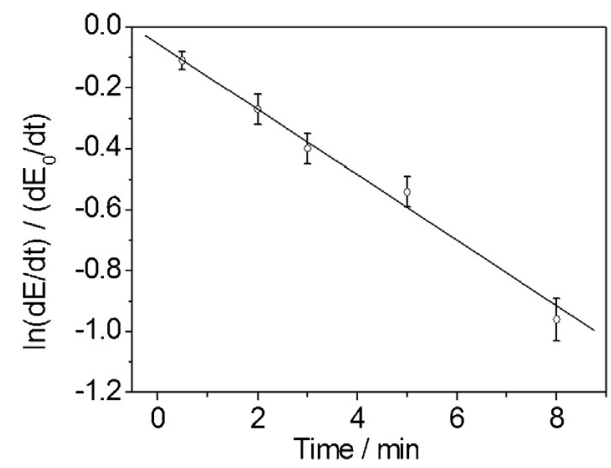

Fig. 4. Results potted as a graph of $\ln (\mathrm{dE} / \mathrm{dt})\left(\mathrm{dE}_{0} / \mathrm{dt}\right)^{-1}$ against inhibition time in the presence of $1 \times 10^{-5} \mathrm{~g} / \mathrm{L}$ MC-LR. Each error bar represents one standard deviation for three measurements.

\subsection{The rate constant for the inhibition of the PP1}

The inhibition constant is an important parameter for an enzyme inhibition assay. The overall rate constant for the inhibition of the PP1 can be given by this equation:

$\ln C_{\mathrm{E}}=\ln C_{\mathrm{E} 0}-K_{i}[\mathrm{I}] \mathrm{t}$

where $[\mathrm{I}]$ is the concentration of the inhibitor, $\mathrm{C}_{\mathrm{E}}$ is the concentration of the non-inhibited enzyme and $\mathrm{C}_{\mathrm{E} 0}$ is the initial concentration of the enzyme $[45,46]$. Eq. (1) can be rearranged to give:

$\ln \frac{C_{\mathrm{E}}}{C_{\mathrm{E} 0}}=-K_{i}[\mathrm{I}] \mathrm{t}$

MC-LR as one of the toxics can be involved in the inhibition action to PP1 thus reduces the enzyme activity. Since the rate of emf change $(\mathrm{dE} / \mathrm{dt})$ of the response curve reflects the enzyme activity during the kinetic inhibition of PP1 by MC-LR in the test solution, Eq. (2) can be expressed as:

$\ln \frac{C_{\mathrm{E}}}{C_{\mathrm{E} 0}}=\ln \left(\frac{\mathrm{dE}}{\mathrm{dt}}\right)\left(\frac{\mathrm{dE}_{0}}{\mathrm{dt}}\right)^{-1}=-K_{i}[\mathrm{I}] \mathrm{t}$

Fig. 4 shows the results plotted as a graph of $\ln (\mathrm{dE} / \mathrm{dt})\left(\mathrm{dE}_{0} / \mathrm{dt}\right)^{-1}$ against inhibition time, in which date are obtained from Fig. 3. Since the inhibition rate and the concentration of inhibitor are available, a value of $K_{i}=(1.1 \pm 0.2) \times 10^{4} \mu \mathrm{g} \mathrm{L}^{-1} \mathrm{~min}^{-1}$ was obtained. This value is in good agreement with the reported value [3].

\subsection{Determination of $M C-L R$}

Under the optimal conditions, the chronopotentiometric method was carried out to detect MC-LR. The enzyme activity of
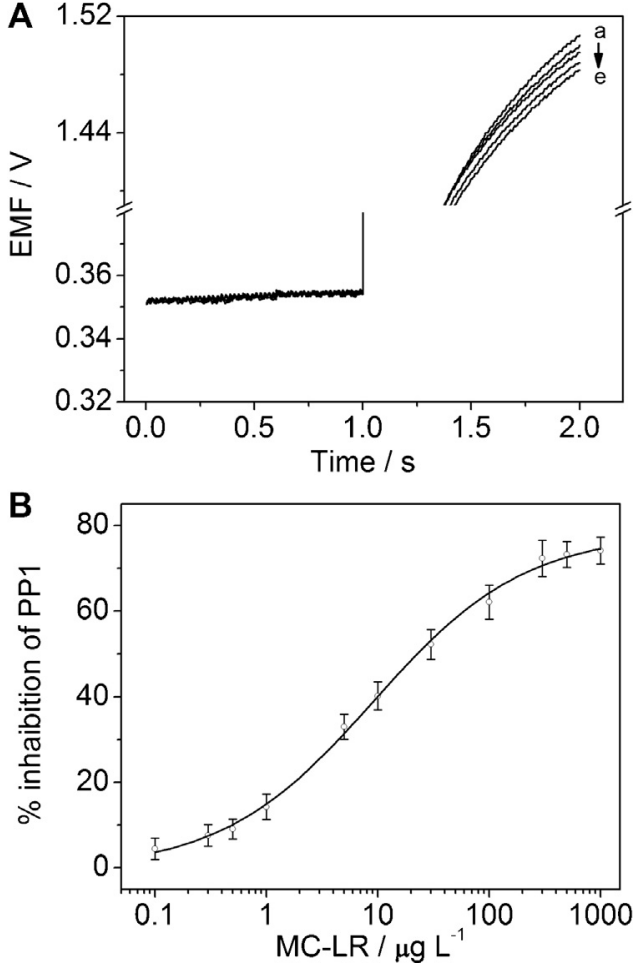

Fig. 5. (A) Potentiometric responses of the electrode in enzyme buffer (a), $1 \times 10^{-3}$ (b), $1 \times 10^{-4}$ (c), $1 \times 10^{-5}$ (d), and $0 \mathrm{~g} / \mathrm{L}$ MC-LR (e). The MC-LR was mixed with $20 \mathrm{U} / \mathrm{mL}$ PP1 in enzyme buffer. Then, the PP1 were incubated in $50 \mu \mathrm{L}$ enzyme buffer contained $50 \mathrm{mM} p$-NPP at $30^{\circ} \mathrm{C}$ for $5 \mathrm{~min}$. The other conditions are as given in Fig. 3 . (B) The calibration curve for the inhibition of PP1 by MC-LR. Each error bar represents one standard deviation for three measurements.

PP1 was inhibited by MC-LR and thus the current-dependent potential changes increased proportionally to the MC-LR concentration. As shown in Fig. 5A, a current-dependent potential differences observed for MC-LR with concentrations greater than $0.1 \mu \mathrm{g} / \mathrm{L}$. The MC-LR can be detected with a linear range from 1 to $100 \mu \mathrm{g} / \mathrm{L}$ with a detection limit of $0.5 \mu \mathrm{g} / \mathrm{L}$ ( $3 \sigma$, Fig. 5B). The detection limit for MC-LR obtained by the proposed method compares favorably with other electrochemical biosensors $[47,48]$. In terms of the sources of interference, the proposed potentiometric assay is better suited for colored and turbid samples (Table 1). It should be noted that the sensitivity can be improved with recombinant PP1. Moreover, it is possible to localize the enzyme on the ISE membrane surface to develop highly sensitive potentiometric biosensors for MCs.

\section{Conclusions}

In conclusion, a solid-contact ion-selective electrode has been designed for chronopotentiometric detection of MC-LR based on enzymatic inhibition. The pulsed galvanastatic technique can precisely control the extraction of the enzymatic generated anions into the polymeric membrane, which leads to the chronopotentiometric signal and enables rapid, reversible and reproducible potentiometric detection of MCs. By choosing an appropriate substrate ion, the proposed chronopotentiometric method can be extended to other enzymatic systems. Very recently, transition time has been shown to be a very promising readout for pulsed galvanostatic sensors. Therefore, we believe that the pulsed galvanostatic technique opens the way for further applications of solid-contact ion-selective electrode in potentiometric biosensing. 
Table 1

Comparison of protein phosphatase inhibition (PP1) assays available for analysis of MC-LR.

\begin{tabular}{|c|c|c|c|}
\hline Method & Comments & Limit of detection & Reference \\
\hline Colorimetric & Low sensitivity, interferences from color and turbidity ${ }^{a}$ & $0.25-2.5 \mu \mathrm{g} / \mathrm{L}$ & {$[3,49]$} \\
\hline Fluorometric & Sensitive, interferences from color and turbidity & $0.1 \mu \mathrm{g} / \mathrm{L}$ & {$[49,50]$} \\
\hline Amperometric & Sensitive, oxides on the electrode surface may cause electrode fouling & $0.1 \mu \mathrm{g} / \mathrm{L}$ & {$[2,51]$} \\
\hline Potentiometric & Rapid, sensitive, resistance to interferences from color and turbidity & $0.5 \mu \mathrm{g} / \mathrm{L}$ & Present \\
\hline
\end{tabular}

a The sensitivity can be improved with recombinant PP1

\section{Acknowledgements}

This work was financially supported by the National Natural Science Foundation of China (21207156, 21575158 and 41176081), the Youth Innovation Promotion Association of CAS (2013139), the Taishan Scholar Program of Shandong Province, and Zhejiang Provincial Natural Science Foundation (LY14B070013) and Public Beneficial Project (2015C33306).

\section{References}

[1] P. Rajesh, R.P. Rastogi, A.I. Sinha, The cyanotoxin-microcystins: current overview, Rev. Environ. Sci. Biotechnol. 13 (2014) 215-249.

[2] G. Catanante, L. Espin, J.L. Marty, Sensitive biosensor based on recombinant PP1alpha for microcystin detection, Biosens. Bioelectron. 67 (2015) 700-707.

[3] A. Sassolas, G. Catanante, D. Fournier, J.L. Marty, Development of a colorimetric inhibition assay for microcystin-LR detection: comparison of the sensitivity of different protein phosphatases, Talanta 85 (2011) 2498-2503.

[4] J. Jacoby, M. Burghdoff, G. Williams, L. Read, J. Hardy, Dominant factors associated with microcystins in nine midlatitude, maritime lakes, Inland Waters 5 (2015) 187-202.

[5] D.W. Zhang, Q.G. Liao, L. Zhang, D.G. Wang, L.G. Luo, Y.W. Chen, Occurrence and spatial distributions of microcystins in Poyang Lake, the largest freshwater lake in China, Ecotoxicology 24 (2015) 19-28.

[6] WHO, Guidelines for drinking-water quality, Addendum to vol.1, 2nd ed., World Health Organization, Geneva, 1998.

[7] T.A.M. Msagati, B.A. Siame, D.D. Shushu, Evaluation of methods for the isolation, detection and quantification of cyanobacterial hepatotoxins, Aquat Toxicol. 78 (2006) 382-397.

[8] A. Gambaro, E. Barbaro, R. Zangrando, C. Barbante, Simultaneous quantification of microcystins and nodularin in aerosol samples using high-performance liquid chromatography/negative electrospray ionization tandem mass spectrometry, Rapid Commun. Mass Spectrom. 26 (2012) 1497-1506.

[9] H.R. Shamsollahi, M. Alimohammadi, R. Nabizadeh, S. Nazmara, A.H. Mahvi, Measurement of microcystin-LR in water samples using improved HPLC method, Glob. J. Health Sci. 7 (2015) 66-70.

[10] G. Vasas, A. Gaspar, C. Pager, G. Suranyi, C.M.M. Mathe, G. Borbely, Analysis of cyanobacterial toxins (anatoxin-a cylindrospermopsin, microcystin-LR) by capillary electrophoresis, Electrophoresis 25 (2004) 108-115.

[11] S. Singh, A. Srivastava, H.M. Oh, C.Y. Ahn, G.G. Choi, R.K. Asthana, Recent trends in development of biosensors for detection of microcystin, Toxicon 60 (2012) 878-894

[12] M. Lotierzo, R. Abuknesha, F. Davis, I.E. Tothill, A membrane-based ELISA assay and electrochemical immunosensor for microcystin-LR in water samples, Environ. Sci. Technol. 46 (2012) 5504-5510.

[13] L. Reverte, D. Garibo, C. Flores, J. Diogene, J. Caixach, M. Campas, Magnetic particle-based enzyme assays and immunoassays for microcystins: from colorimetric to electrochemical detection, Environ. Sci. Technol. 47 (2013) 471-478.

[14] W. Ma, W. Chen, R.R. Qiao, C.Y. Liu, C.H. Yang, Z.K. Li, Rapid and sensitive detection of microcystin by immunosensor based on nuclear magnetic resonance, Biosens. Bioelectron. 25 (2009) 240-243.

[15] S. Eissa, A. Ng, M. Siaj, M. Zourob, Label-free voltammetric aptasensor for the sensitive detection of microcystin-LR using graphene-modified electrodes, Anal. Chem. 86 (2014) 7551-7557.

[16] A. Ng, R. Chinnappan, S. Eissa, H. Liu, C. Tlili, M. Zourob, Selection characterization, and biosensing application of high affinity congener-specific microcystin-targeting aptamers, Environ. Sci. Technol. 46 (2012) 10697-10703.

[17] T. Ikehara, S. Imamura, N. Oshiro, S. Ikehara, F. Shinjo, T. Yasumoto, A protein phosphatase 2A (PP2A) inhibition assay using a recombinant enzyme for rapid detection of microcystins, Toxicon 51 (2008) 1368-1373.

[18] R.M. Dawson, The toxicology of microcystins, Toxicon 36 (1998) 953-962.

[19] M. Campas, D. Szydlowska, M. Trojanowicz, J.L. Marty, Enzyme inhibition-based biosensor for the electrochemical detection of microcystins in natural blooms of cyanobacteria, Talanta 72 (2007) 179-186.

[20] O.I. Covaci, A. Sassolas, G.A. Alonso, R. Munoz, G.L. Radu, B. Bucur, Highly sensitive detection and discrimination of LR and YR microcystins based on protein phosphatases and an artificial neural network, Anal. Bioanal. Chem. 404 (2012) 711-720.

[21] S. Herranz, M. Bockova, M.D. Marazuela, J. Homola, M.C. Moreno-Bondi, An SPR biosensor for the detection of microcystins in drinking water, Anal. Bioanal. Chem. 398 (2010) 2625-2634.

[22] K.Y. Chumbimuni-Torres, Z. Dai, N. Rubinova, Y. Xiang, E. Pretsch, J. Wang, E. Bakker, Potentiometric biosensing of proteins with ultrasensitive ion-selective microelectrodes and nanoparticle labels, J. Am. Chem. Soc. 128 (2006) 13676-13677.

[23] J. Szücsa, E. Pretschb, R.E. Gyurcsányi, Potentiometric enzyme immunoassay using miniaturized anion selective electrodes for detection, Analyst 134 (2009) 1601-1607.

[24] M.S. Ozdemir, M. Marczak, H. Bohets, K. Bonroy, D. Roymans, L. Stuyver, K. Vanhoutte, M. Pawlak, E. Bakker, A label-free potentiometric sensor principle for the detection of antibody-antigen interactions, Anal. Chem. 85 (2013) 4770-4776.

[25] J.W. Ding, Y. Chen, X.W. Wang, W. Qin, Label-free and substrate-free potentiometric aptasensing using polycation-sensitive membrane electrodes, Anal. Chem. 84 (2012) 2055-2061.

[26] J.W. Ding, Y. Gu, F. Li, H.X. Zhang, W. Qin, DNA nanostructure-based magnetic beads for potentiometric aptasensing, Anal. Chem. 87 (2015) 6465-6469.

[27] A. Shvarev, E. Bakker, Pulsed galvanostatic control of ionophore-based polymeric ion sensors, Anal. Chem. 75 (2003) 4541-4550.

[28] G.A. Crespo, E. Bakker, Dynamic electrochemistry with ionophore basedion-selective membranes, RSC Adv. 3 (2013) 25461-25474.

[29] M.A. Peshkova, E.S. Koltashova, G.A. Khripoun, K.N. Mikhelson, Improvement of the upper limit of the ISE Nernstian response by tuned galvanostatic polarization, Electrochim. Acta 167 (2015) 187-193.

[30] S. Makarychev-Mikhailov, A. Shvarev, E. Bakker, Calcium pulstrodes with 10 -fold enhanced sensitivity for measurements in the physiological concentration range, Anal. Chem. 78 (2006) 2744-2751.

[31] K.L. Gemene, M.E. Meyerhoff, Reversible detection of heparin and other polyanions by pulsed chronopotentiometric polymer membrane electrode, Anal. Chem. 82 (2010) 1612-1615.

[32] E. Bakker, Enhancing ion-selective polymeric membrane electrodes by instrumental control, TrAC-Trends Anal. Chem. 53 (2014) 98-105.

[33] M. Ghahraman Afshar, G.A. Crespo, E. Bakker, Direct ion speciation analysis with ion-selective membranes operated in a sequential potentiometric/time resolved chronopotentiometric sensing mode, Anal. Chem. 84 (2012) $8813-8821$.

[34] G.A. Crespo, M. Ghahraman Afshar, E. Bakker, Direct detection of acidity alkalinity, and pH with membrane electrodes, Anal. Chem. 84 (2012) 10165-10169.

[35] G.A. Crespo, M. Ghahraman Afshar, E. Bakker, Reversible sensing of the anticoagulant heparin with protamine permselective membranes, Angew. Chem. Int. Ed. 51 (2012) 12575-12578.

[36] Z. Jarolímovaí, G.A. Crespo, X.J. Xie, M. Ghahraman Afshar, M. Pawlak, E. Bakker, Chronopotentiometric carbonate detection with all-solid-state ionophore-based electrodes, Anal. Chem. 86 (2014) 6307-6314.

[37] U. Vanamo, J. Bobacka, Electrochemical control of the standard potential of solid-contact ion-selective electrodes having a conducting polymer as ion-to-electron transducer, Electrochim. Acta 122 (2014) 316-321.

[38] K. Fordyce, A. Shvarev, Solid-contact electrochemical polyion sensors for monitoring peptidase activities, Anal. Chem. 80 (2008) 827-833.

[39] J.H. Li, T.J. Yin, W. Qin, An all-solid-state polymeric membrane $\mathrm{Pb}^{2+}$-selective electrode with bimodal pore C60 as solid contact, Anal. Chim. Acta 876 (2015) 49-54.

[40] J.W. Ding, W. Qin, Current-driven ion fluxes of polymeric membrane ion-selective electrode for potentiometric biosensing, J. Am. Chem. Soc. 131 (2009) 14640-14641.

[41] J.W. Ding, X.W. Wang, W. Qin, Pulsed galvanostatic control of a polymeric membrane ion-selective electrode for potentiometric immunoassays, ACS App. Mater. Interfaces 5 (2013) 9488-9493.

[42] D. Nilsson, N. Robinson, M. Berggren, R. Forchheimer, Electrochemical logic circuits, Adv. Mater. 17 (2005) 353-357.

[43] A. Michalska, A. Gałuszkiewicz, M. Ogonowska, M. Ocypa, K. Maksymiuk, PEDOT films: multifunctional membranes for electrochemical ion sensing, J. Solid State Eletrochem. 8 (2004) 381-389.

[44] H. Perera, K. Fordyce, A. Shvarev, Pulsed galvanostatic control of solid-state polymeric ion-selective electrodes, Anal. Chem. 79 (2007) 4564-4573.

[45] V. Pavlov, Y. Xiao, I. Willner, Inhibition of the acetycholine esterase-stimulated growth of Au nanoparticles: nanotechnology-based sensing of nerve gases, Nano Lett. 5 (2005) 649-653. 
[46] J.W. Ding, W. Oin, Polymeric membrane ion-selective electrode for butyrylcholinesterase based on controlled release of substrate, Electroanalysis 21 (2009) 2030-2035

[47] M. Campas, D. Szydlowska, M. Trojanowicz, J.L. Marty, Towards the protein phosphatase-based biosensor for microcystin detection, Biosens. Bioelectron. 20 (2005) 1520-1530.

[48] R.B. Queirós, J.P. Noronha, P.V.S. Marques, M.G.F. Sales, Label-free detection of microcystin-LR in waters using real-time potentiometric biosensors based on single-walled carbon nanotubes imprinted polymers, Procedia Eng. 47 (2012) 758-761.

[49] N. Bouaicha, I. Maatouk, G. Vincent, Y. Levi, A colorimetric and fiuorometric microplate assay for the detection of microcystin-LR in drinking water without preconcentration, Food Chem. Toxicol. 40 (2002) 1677-1683.

[50] J. Rapala, K. Erkomaa, J. Kukkonen, K. Sivonen, K. Lahti, Detection of microcystins with protein phosphatase inhibition assay, high-performance liquid chromatography-UV detection and enzymelinked immunosorbent assay-comparison of methods, Anal. Chim. Acta 466 (2002) 213-231.

[51] M. Campas, M.G. Olteanu, J.L. Marty, Enzymatic recycling for signal amplification: improving microcystin detection with biosensors, Sens. Actuators B 129 (2008) 263-267.

\section{Biographies}

Nana Yu is pursuing a Master's degree at Wenzhou Medical University. Now she is a member of the Joint Postgraduate Program with Yantai Institute of Coastal Zone Research, Chinese Academy of Sciences.
Jiawang Ding received his doctor's degree from Yantai Institute of Coastal Zone Research, Chinese Academy of Sciences in 2011. Presently, he is an associate professor in this institute. His current research interests focus on electrochemical biosensors.

Wenwei Wang is currently an assistant researcher in Wenzhou Medical University.

Xuedong Wang received his doctor's degree from Zhejiang University in 2003. He has been working as professor in Wenzhou Medical University since 2008. His research interests include separation and analysis of environmental pollutants.

Wei Qin received his doctor's degree from Nanjing University in 1998. From 1999 to 2003, he did his postdoctoral research at Swiss Federal Institute of Technology (ETH), University of South Carolina and University of Michigan, respectively. He has been working as professor at Yantai Institute of Coastal Zone Research, Chinese Academy of Sciences since 2006. His research interests include chemical sensors and biosensors for environmental analysis. 